\title{
Virilisation due to an ovarian steroid cell tumour in a child with Turner syndrome
}

\author{
P S Samarakoon ${ }^{1}$, A L P Wijesuriya ${ }^{2}$, K S H de Silva ${ }^{3}$ \\ Sri Lanka Journal of Child Health, 2010; 39:26-28
}

(Key words: virilisation, Turner syndrome, steroid cell tumour)

This is the story of a girl previously diagnosed to have non-salt losing congenital adrenal hyperplasia presenting with progressive virilisation in spite of adequate replacement therapy is presented.

\section{Case report}

A 4 years and 10 months old girl had presented to a tertiary care hospital with enlarged clitoris and Tanner stage II pubic hair. Her mother had noted these changes since 2 years of age. However, there was no breast enlargement or vaginal bleeding. Trans-abdominal ultra sound scan had been normal, but ovaries were not visualised. Her serum 17-hydroxy-progesterone level was $2.8 \mathrm{ng} / \mathrm{ml} \quad(0.07-1.7)$. She was diagnosed as having non salt losing congenital adrenal hyperplasia (NSL-CAH). She had been started on hydrocortisone $\left(10 \mathrm{mg} / \mathrm{m}^{2} /\right.$ day $)$ and fludrocortisone.

At 6 years she presented with a hoarse voice, hirsutism and acne. Her height was $127 \mathrm{~cm}$ (Figure 1) with a velocity well over the $97^{\text {th }}$ centile.

\section{Senior Registrar in Paediatrics, Consultant Paediatrician, Lady Ridgeway Hospital, Colombo 8, Senior Lecturer, Department of Paediatrics, Faculty of Medicine, University of Colombo}

Received on 23 September 2008. Accepted on 23 January 2009)

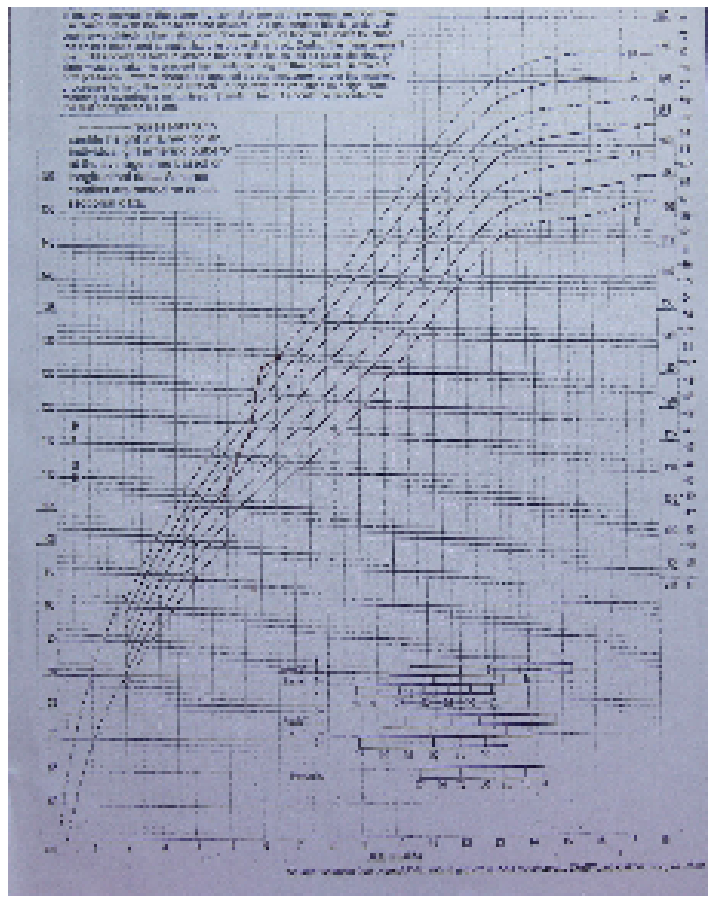

Figure 1 Patient's height plotted on a NCHS chart.

She had Tanner stage II axillary hair, Tanner stage III pubic hair without any breast development. Examination of the other systems was normal with normal blood pressure. She was re- investigated since the clinical features were progressing in spite of treatment and good compliance Results of investigations are given in table 1 . 
Table 1

Results of investigations

\begin{tabular}{|l|c|c|}
\hline \multicolumn{1}{|c|}{ Investigation } & Result & Reference range \\
\hline Free testosterone & $77.5 \mathrm{pg} / \mathrm{ml}$ & $0.15-0.6 \mathrm{pg} / \mathrm{ml}$ \\
\hline Dehydroepiandrosterone sulphate (DHEA-S) & $1.0 \mathrm{mcg} / \mathrm{ml}$ & $0.25-1 \mathrm{mcg} / \mathrm{ml}$ \\
\hline 17-hydroxy progesterone & $6.1 \mathrm{ng} / \mathrm{ml}$ & $0.07-1.7 \mathrm{ng} / \mathrm{ml}$ \\
\hline Follicular stimulating hormone & $7.2 \mathrm{miu} / \mathrm{ml}$ & $1-3 \mathrm{miu} / \mathrm{ml}$ \\
\hline Leutinising hormone & $2.1 \mathrm{miu} / \mathrm{ml}$ & $1-5 \mathrm{miu} / \mathrm{ml}$ \\
\hline Alpha-fetoprotein & $0.7 \mathrm{ng} / \mathrm{ml}$ & $1-15 \mathrm{ng} / \mathrm{ml}$ \\
\hline Beta-human chorionic gonadotrophin & $0.2 \mathrm{miu} / \mathrm{ml}$ & 1 less than $5 \mathrm{miu} / \mathrm{ml}$ \\
\hline Serum sodium & $140 \mathrm{mmol} / 1$ & $138-145 \mathrm{mmol} / 1$ \\
\hline Serum potassium & $4.4 \mathrm{mmol} / 1$ & $3.5-5 \mathrm{mmol} / 1$ \\
\hline Random blood sugar & $96 \mathrm{mg} / \mathrm{dl}$ & $60-100 \mathrm{mg} / \mathrm{dl}$ \\
\hline Bone age (left hand / wrist) & 8 years and $10 \mathrm{months}$ & -- \\
\hline
\end{tabular}

Trans-abdominal-ultrasound scan showed a mass arising from the left ovary. Right ovary and the adrenal glands were normal. An abdominal CT scan confirmed a well defined rounded soft tissue mass $(2.94 \times \quad 2.77 \mathrm{~cm})$ without calcification arising from the left ovary; there were no para-aortic lymphadenopathy or free fluid in the abdomen.

An androgen secreting tumour was suspected and a left oophorectomy was performed at laparotomy which also revealed a streak right ovary from which a biopsy was taken. Histology revealed an encapsulated tumour of left ovary with abundant granular eosinophillic cytoplasm and inconspicuous stromal component. Crystals of Reinke were not seen. Appearance was in keeping with a steroid cell tumour not otherwise specified, nuclear grade I with no mitotic activity. Excision appeared complete. Biopsy of streak right gonad showed fibroblastic tissue suggestive of ovarian stroma.

There were no clinical features of Turner syndrome in our patient but a karyotype was done in view of the streak gonad and this was found to be $46, X$, $\operatorname{idic}(X)$ (q22), one $X$ chromosome being a dicentric isochromosome (Figure 2).

Fourteen days after excision of the tumour serum free testosterone level was less than $0.1 \mathrm{pg} / \mathrm{ml}$. Virilisation gradually reduced and seven months after excision of the tumour her height was 128 $\mathrm{cm}\left(97^{\text {th }}\right.$ centile) with a velocity of $3.4 \mathrm{~cm} /$ year (below $3^{\text {rd }}$ centile) and weight had reduced to $22.5 \mathrm{~kg}$ (Figure 3), confirming that the steroid cell tumour was the underlying cause of the virilization.

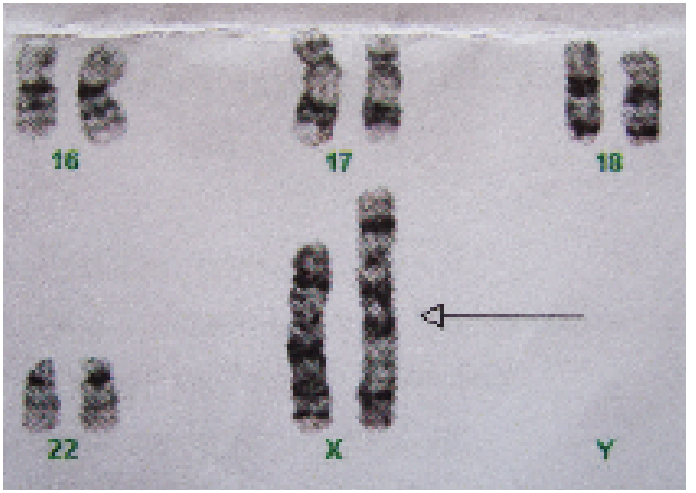

Figure 2 Section of karyotype showing dicentric isochromosome $X$ (shown by arrow).

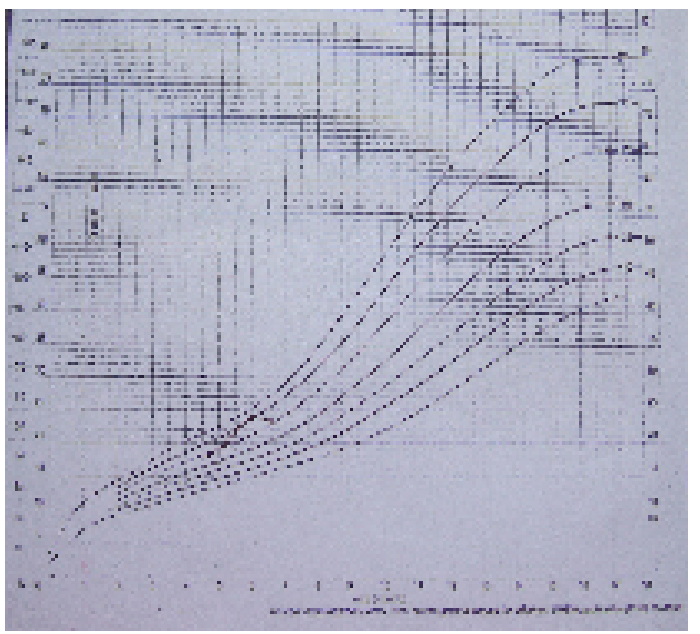

Figure 3 Patients weight plotted on a NCHS chart

Axillary hair had disappeared and there was a marked reduction in hirsutism and pubic hair (Tanner stage II) but the hoarse voice persisted. 


\section{Discussion}

Virilising ovarian tumours are rare in children ${ }^{1}$ An eleven year review of endocrine manifestations of ovarian tumours had reported only one child out of 26 with virilisation which was due to a Sertoli-Leydig cell tumour.

Ovarian steroid cell tumors can be divided into different categories according to their originating cells $^{2}$. However, the cellular origin of a large subset is uncertain, and this group has been frequently designated 'not otherwise specified'. Steroid cell tumours are rare in children ${ }^{3}$. These tumours commonly secrete testosterone ${ }^{4}$ but are known to cause isosexual or heterosexual precocious pseudopuberty $^{3,4,5}$ and are thought to be benign when they occur in prepubertal children $^{3}$.

Eleven to fifteen percent of girls with Turner syndrome have isochromosomes ${ }^{6}$. Turner syndrome due to $46, \mathrm{X}, \operatorname{idic}(\mathrm{X})$ (q22) karyotype is rare $^{7}$. This girl did not have any dysmorphic features of Turner syndrome ${ }^{8,9}$ but she was tall. Investigations did not reveal any cardiac or renal complications. There are other case reports of Turner syndrome patients with the same karyotype who had normal growth, development and no dysmorphism ${ }^{10}$ while one other report indicated mild dysmorphism ${ }^{7}$.

Turner syndrome patients who have whole or parts of $\mathrm{Y}$ chromosome are known to have a higher risk of ovarian gonadoblastomas ${ }^{11}$. Deletions of $\mathrm{Xq}$ are known to be associated rarely with myelodysplastic syndromes (MDS) and refractory anaemia with excess blasts $(\text { RAEB })^{12}$. No other reports were found indicating increased incidence of tumours in 46, $\mathrm{X}$, $\operatorname{idic}(\mathrm{X})(\mathrm{q} 22)$ karyotype.

The commonest cause for the rare manifestation of virilisation in a girl presenting in childhood is NSL-CAH. But if the clinical features are progressive with an increasing height velocity in spite of adequate replacement therapy reinvestigation and a review of the diagnosis are indicated.

\section{References}

1. de Silva KSH, Warne GL. Endocrine manifestations of ovarian lesions in children: an 11 year review. Sri Lanka Journal of Child Health 2001; 30: 60-5
2. Scully RE, Young RH, Clement PB. Tumors of ovary, maldeveloped gonads, fallopian tube and broad ligaments. In: Atlas of tumor pathology, series 3, fascicule 23. Washington, DC: Armed Forces Institute of Pathology; 1998. p. 27-31.

3. Harris AC, Wakely PE Jr, Kaplowitz PB, Lovinger RD. Steroid cell tumor of the ovary in a child. Archives of Pathology and Laboratory. Medicine 1991; 115 (2):150-4.

4. Reedy MB, Richards WE, Ueland F, Uy K, Lee EY, Bryant C, et al. Ovarian steroid cell tumors, not otherwise specified: A case report and literature review. Journal of Gynecologic Oncology 1999; 75 (2): 293-7

5. Lin CJ, Jorge AA, Latronico AC, Marui S, Fragoso MC, Martin RM, et al. Origin of an ovarian steroid cell tumor causing isosexual pseudoprecocious puberty demonstrated by the expression of adrenal steroidogenic enzymes and adrenocorticotropin receptor. Journal of Clinical Endocrinology and Metabolism 2000; 85 (3):1211-4

6. Texas Department of Health Services [homepage on the internet]. Austin: Birth Defect Risk factor series, Turner syndrome: c2002-2005 May 23 [cited 2008 September 15]. Available from:

http://www.dshs.state.tx.us/birthdefects/risk/ risk25-turner.shtm

7. Petković I, Barisić I, Bago R. Cytogenetic evaluation, fluorescence in situ hybridization, and molecular study of psu $\operatorname{idic}(X)$ (pter-->q22.3::q22.3-->pter)

chromosome aberration in a girl with moderate growth retardation. Croatian Medical Journal 2003; 44 (4):494-9.

8. Saenger P, Wikland KA, Conway GS, Davenport M, Gravholt CH, Hintz S, et al. Recommendations for the Diagnosis and Management of Turner Syndrome. Journal of Clinical Endocrinology and Metabolism 2001; 86 (7): 3061-9.

9. Saenger P. Turner's Syndrome. The New England Journal of Medicine. 1996; 335:1749-54. 
10. Tsai ACH, Fine CA, Yang M, Walton CS , Beischel L, Johnson JP. De novo isodicentric X chromosome: $46, \mathrm{X}, \operatorname{idic}(\mathrm{X})$ (q24), and summary of literature. American Journal of Medical Genetics Part A.2006; 140A (8): 923-30.

11. Gravholt CH, Fedder J, Naeraa RW, Müller J. Occurrence of Gonadoblastoma in Females with Turner Syndrome and Y Chromosome Material: A Population Study.
Journal of Clinical Endocrinology and Metabolism 2000; 85 (9): 3199-202

12. Olshanskaya Y, Udovichenko A, Vodinskaya L, Glasko E, Parovitchnikova E, Lorie Y, et al. Myelodysplastic syndromes with isolated deletion of the long arm of the chromosome $\mathrm{X}$ as a sole cytogenetic change. Cancer Genetics and Cytogenetics. 2003; 167 (1): $47-50$. 